\title{
Effect of organic manures, PGPR and micronutrients on yield and quality enhancement in ajwain (Trachyspermum ammi $\mathrm{L}$ )
}

\author{
G S Thanuja ${ }^{1 *}$, B Srinivasulu ${ }^{1}, K^{2}$ M Yuvaraj ${ }^{1} \&$ K Giridhar $^{2}$ \\ ${ }^{1}$ College of Horticulture, Dr YSR Horticultural University, Anantharajupeta-516 105, Kadapa, Andhra Pradesh. \\ ${ }^{2}$ AICRP on Spices, Dr. YSRHU, Lam, Guntur, Andhra Pradesh. \\ ${ }^{*}$ E-mail: th_09@rediffmail.com
}

Received 05 November 2020; Revised 14 May 2021; Accepted 17 May 2021

\begin{abstract}
Experiments were conducted for two consecutive years during 2017-19 to study the effect of organic manures, PGPR and micronutrients on yield and quality of ajwain seed. Farm yard manure (FYM) and vermicompost (VC) were used as organic sources at $50 \%$ and $75 \%$ recommended dose of nitrogen (RDN) as basal dose. PGPRs namely Azospirillum lipoferum, Bacillus megaterium and Frateuria aurantia were used for seed priming. Micronutrients namely $\mathrm{ZnSO}_{4}$ and $\mathrm{Fe}_{2} \mathrm{SO}_{4}$ were applied thrice as foliar application @ 0.5\% first before flowering, second at $50 \%$ flowering and third during grain formation. The results revealed that highest number of umbels plant ${ }^{-1}$, umbellets umbel $^{-1}$, number of fruits umbellet ${ }^{-1}$, seed yield plant $^{-1}$, seed yield hectare ${ }^{-1}$, straw yield, biological yield, test weight of seeds and essential oil yield were recorded with the application of $50 \%$ RDN through VC, which was on par with 50\% RDN through FYM, seed priming with Azospirillum and foliar application of zinc with respect to their individual effect. Maximum essential oil content, fixed oil content and thymol content were also observed in case of application of $50 \%$ RDN through VC, seed priming with Azospirillum and foliar application of zinc individually. Highest Benefit Cost Ratio (BCR) of 3.33 was recorded with combined application of $50 \%$ of RDN through FYM along with seed priming with Azospirillum and foliar spray of $\mathrm{Zn}$ at $0.5 \%$.
\end{abstract}

Keywords: Azospirillum lipoferum, Bacillus megaterium, Frateuria aurantia, thymol

\section{Introduction}

Ajwain is an aromatic seed spice, cultivated mainly for its seed, herb and volatile oil. Seed possesses stimulant, antispasmodic and carminative properties and used traditionally as an important remedial agent for flatulence, abdominal tumors, diarrhoea and bronchial problems etc. Usually, thymol is the main essential oil constituent and its yield varies from $35 \%$ to $60 \%$ (Sega \& Kitajima 2001; Zarshenas et al. 2014). Being a cash crop, ajwain is getting importance among the farmers of Rayalaseema region of Andhra Pradesh, as against the traditional crop, as farmers are interested in diversification of cropping pattern through 
the short duration seed species like ajwain, coriander, fennel, cumin etc.

Application of organic manures like vermicompost (VC) and farm yard manure (FYM) in combination with PGPR is one of the promising practice to maximize the productivity in a sustainable manner. Thus the inorganic sources of nutrients need to be substituted with the organic manures and applied along with biofertilizers to maintain soil health and environmental safety. So far, research on plant nutrition has mainly concentrated on the levels of chemical fertilizers in various combinations in order to evoke a quick response even at the cost of decrease in long term fertility of soil. Deficiency of iron is a serious problem under conditions of high $\mathrm{pH}$ (above 7.5) and high soil phosphorus contents. The soil of Anantharajupeta where the present experiment was conducted is having high phosphorus content. High soil phosphorus in conjunction with high $\mathrm{pH}$ further aggravates zinc deficiency (Hopkins 1995). Very limited research work on nutrient management in seed spices is done in Rayalaseema region of Andhra Pradesh. Research on the performance of organically grown ajwain with plant growth promoting rhizobacteria and micronutrient sprays helps in restructuring of nutrient doses for obtaining economic yields with sustainable soil health. Keeping these points in view, the present study was conducted with improved management practices coupled with the use of organic manures, PGPR and secondary micronutrients to improve nutritive value and productivity of ajwain.

\section{Material and methods}

The study was carried out at the College of Horticulture, Anantharajupeta, Andhra Pradesh during 2017-18 and 2018-19. LTa-26 variety of ajwain released by Dr. Y.S.R.H.U was used for the study. The experiment consisted of 25 treatments, laid out in Factorial RBD with single control design and replicated thrice. The treatments comprised of different combinations of organic manures, PGPRs and micronutrients. Farm yard manure and vermicompost were used as organic source (Factor A) at 50\% and 75\% recommended dose of nitrogen (RDN). The NPK content (\%) in FYM was $0.5,0.2$ and 0.5 and in vermicompost was 1.5, 0.9 and 1.5. PGPRs (Factor B) namely Azospirillum lipoferum, Bacillus megaterium and Frateuria aurantia were used for seed priming (@ $5 \mathrm{~g} \mathrm{~kg}^{-1}$ of seed) and micronutrients (Factor C) namely, $\mathrm{ZnSO}_{4}$ and $\mathrm{Fe}_{2} \mathrm{SO}_{4}$ were applied as foliar spray @ 0.5\% before flowering at 60 days after sowing (DAS), 50\% flowering (90 DAS) and during grain formation (120 DAS) stages and the single control was RDN @20 kg ha-1. The recommended dose of $\mathrm{N}, \mathrm{P}$ and $\mathrm{K}$ were applied in the form of urea, single super phosphate and muriate of potash. Nitrogen was applied in 3 splits; $1 / 3$ nitrogen was applied at sowing as basal and remaining in two equal splits at 30 and 60 DAS. Organic manures were applied as per the treatments one week before sowing. An uniform dose of $40 \mathrm{~kg} \mathrm{P}_{2} \mathrm{O}_{5}$ and $20 \mathrm{~kg} \mathrm{~K}_{2} \mathrm{O}$ was applied through single super phosphate and muriate of potash respectively as basal dose for all the treatments including control.

During the crop growth period, total rainfall received was $820.10 \mathrm{~mm}$. The mean maximum and minimum temperatures ranged from $40.6^{\circ} \mathrm{C}$ to $29.2^{\circ} \mathrm{C}$ and $25.4^{\circ} \mathrm{C}$ to $11.7^{\circ} \mathrm{C}$, respectively. The relative humidity ranged from 69.1 to 89.7 per cent. The results of the soil analysis indicated that the experimental soil belongs to the textural class of sandy loam with good drainage facility, slightly acidic in reaction, low in available organic carbon and nitrogen, medium in phosphorus and high in available potassium. The seeds were sown by adopting a spacing of $35 \times 15 \mathrm{~cm}$ and during first year, sowing was done on 15 October and harvesting was done on 10 March and during second year, seeds were sown on 10 October and harvesting was done on 5 March. All the management practices were carried out as per the recommendations of Dr.YSRHU. Essential oil content $(\%)$ in ajwain seed was determined using Clevenger's apparatus (Anon. 2000) and the total fixed oil extraction from seeds was performed according to Folch et al. (1957). GC- 
MS (QP2010 Plus, Shimadzu, Japan), equipped with an Rtx- 5 MS capillary column $(30.0 \mathrm{~m}$ $\times 0.25 \mathrm{~mm}$ i.e. $0.25 \mu \mathrm{m}$ film thickness) was used for the separation of the components of essential oil and thymol estimation.

The data pertaining to morphological parameters, yield, quality attributes was subjected to statistical analysis (for both the years and the mean of two years) using the procedure outlined by Panse \& Sukhatme (1978).

\section{Results and discussion}

\section{Yield characters}

The results of the study clearly indicated that the individual effect of organic manure, plant growth promoting rhizobacteria and foliar application of micronutrients significantly increased the yield and yield attributes of ajwain(Table 1). Significantly highest number of umbels plant ${ }^{-1}$ (213.98), maximum number of umbellets umbel ${ }^{-1}$ (13.29), number of fruits umbellet $^{-1}$ (21.32), seed yield plant ${ }^{-1}$ (11.29 g), seed yield hectare ${ }^{-1}\left(1239.00 \mathrm{~kg} \mathrm{ha}^{-1}\right)$, test weight of seeds $(1.10 \mathrm{~g})$, straw yield (310.73 $\mathrm{gm}^{-2}$ ), biological yield (4346.31 $\mathrm{kg} \mathrm{ha}^{-1}$ ) and essential oil yield (38.94 $\left.1 \mathrm{ha}^{-1}\right)$ were recorded in treatment that received $50 \%$ of RDN through vermicompost. Also seed priming with Azospirillum recorded significantly highest number of umbels plant ${ }^{-1}$ (207.13), number of umbellets umbel $^{-1}$ (13.10), fruits umbellet $^{-1}$ (21.11), seed yield plant ${ }^{-1}$ (10.99 g), seed yield hectare $^{-1}\left(1211.0 \mathrm{~kg} \mathrm{ha}^{-1}\right)$, test weight of seed $(1.05 \mathrm{~g})$, straw yield $\left(294.72 \mathrm{gm}^{-2}\right)$, biological yield (4158.21 $\mathrm{kg} \mathrm{ha}^{-1}$ ) and essential oil yield (37.52 $\left.1 \mathrm{ha}^{-1}\right)$. In the case of micronutrients application, foliar spray of $\mathrm{ZnSO}_{4}$ at $0.5 \%$ produced significantly higher number of umbels plant ${ }^{-1}$ (202.21), number of umbellets umbel $^{-1}$ (12.90), number of fruits (20.82) umbellet $^{-1}$, seed yield plant $^{-1}(10.74 \mathrm{~g})$, seed yield (1181.32 kg ha-1), test weight of seed (1.02 g), straw yield $\left(283.73 \mathrm{gm}^{-2}\right)$, biological yield $\left(4018.58 \mathrm{~kg} \mathrm{ha}^{-1}\right)$ and essential oil yield (35.92 $\left.1 \mathrm{ha}^{-1}\right)$.
The combined use of organic manures, PGPR and micronutrients could also exert significant influence on yield and yield attributing characters. Significantly highest number of umbels plant ${ }^{-1}$ (226.71), number of umbellets umbel $^{-1}$ (14.13), number of fruits umbellet $^{-1}$ (22.18), seed yield plant ${ }^{-1}$ (12.28 g), seed yield hectare ${ }^{-1}\left(1336.43 \mathrm{~kg} \mathrm{ha}^{-1}\right)$, test weight of seed (1.18 g), straw yield (349.72 $\left.\mathrm{gm}^{-2}\right)$, biological yield (4833.63 $\left.\mathrm{kg} \mathrm{ha}^{-1}\right)$ and essential oil yield (44.91 $\left.1 \mathrm{ha}^{-1}\right)$ were observed in combined application of $50 \%$ of RDN through vermicompost along with seed priming with Azospirillum and foliar application of $\mathrm{ZnSO}_{4}$ which was statistically on par with application of $50 \%$ of RDN through FYM along with seed priming with Azospirillum and foliar application of $\mathrm{ZnSO}_{4}$.

The significant improvement in seed yield of ajwain with the addition of vermicompost might be due to its positive influence on maintaining balanced source and sink relationship. The seed and straw yields being functions of growth and yield attributes improved significantly due to the cumulative effect of these attributes. Further, vermicompost might have increased the efficiency of added chemical fertilizers in soil, activities of $\mathrm{N}$ fixing bacteria and rate of humification. Humic acid in vermicompost could have enhanced the availability of both native and added nutrients in soil and as a result improved growth, yield and yield attributes of the crop significantly (Sreenivas et al. 2000). Application of vermicompost resulted in increased biomass production and further enhanced number of umbel, umbellets, and ultimately seeds plant ${ }^{-1}$. Increased fruit yield in vermicompost treatments could be due to improvement in yield components such as plant height, umbel number plant ${ }^{-1}$, umbellets umbel $^{-1}$ and biomass yield. These findings are in accordance with the observations of Yogesh et al. (2016) and Ravi (2016) in coriander and Shekofteh et al. (2013) in ajwain.

In the present study, the combined effect of organic manures, PGPR and micronutrients on seed yield and yield attributing characters of 


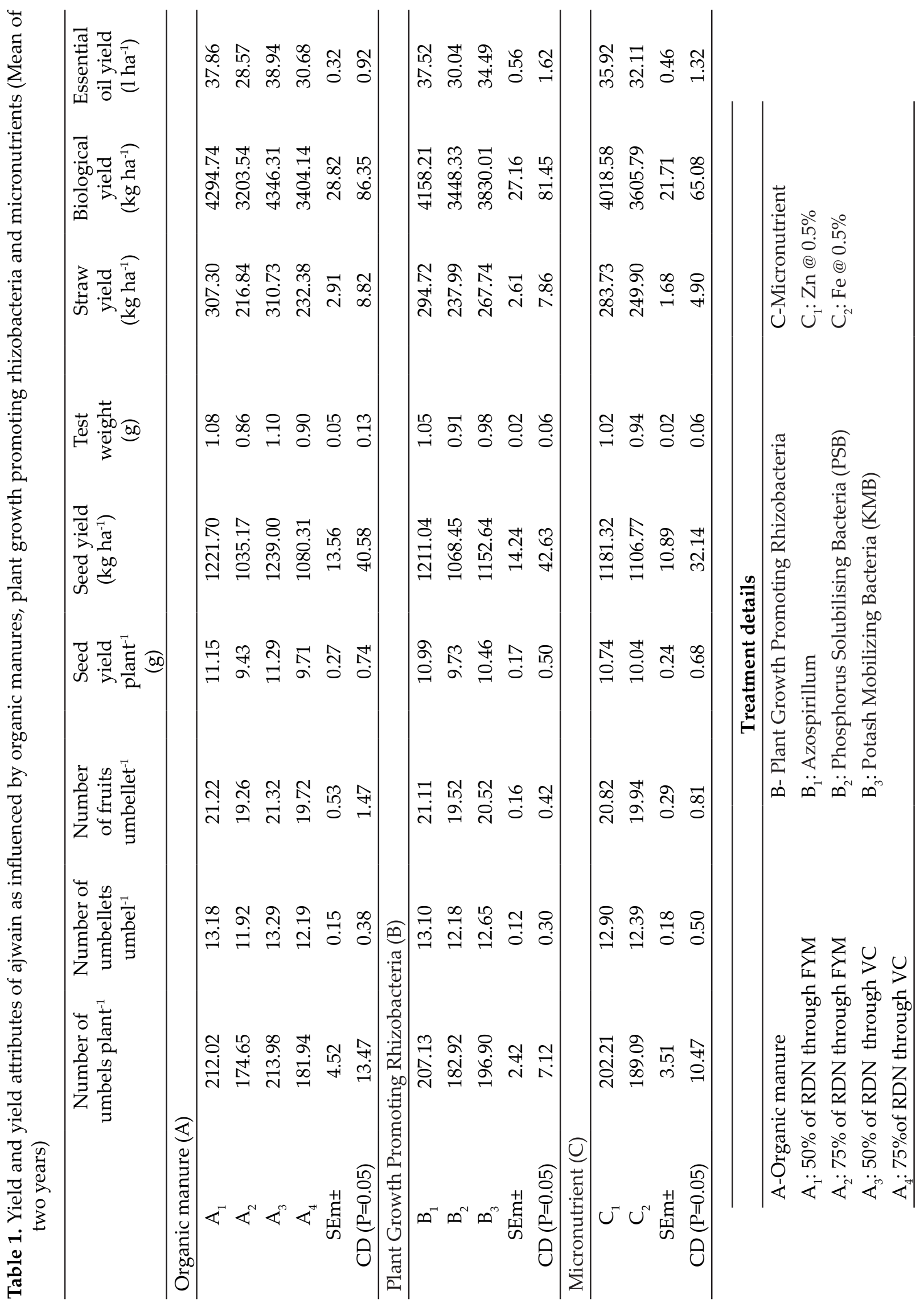


ajwain was significant. Along with nutrients from organic and inorganic sources, PGPR and micronutrients promoted yield and yield attributing characters and also the soil quality. The foliar spray of micronutrients also helped them to function more efficiently. Positive effect of $\mathrm{Zn}$ with respect to number of fruits and yield could be due to the fact that $\mathrm{Zn}$ favours the enzyme system, auxin, and protein synthesis and seed production directly or indirectly (Sharma et al. 1999).

\section{Quality parameters}

The data presented in Table 2 showed that there was a significant difference in essential oil content, fixed oil content and thymol of ajwain with respect to the individual effect of organic manures, PGPR and micronutrients in both the years. Significantly maximum essential oil content (3.14\%), fixed oil content $(8.63 \%)$ and thymol content $(47.89 \%)$ were recorded in the treatment that received $50 \%$ of RDN through vermicompost. Among the plant growth promoting rhizobacteria, seed priming with Azospirillum resulted in significantly high essential oil content (3.09\%), fixed oil content $(8.51 \%)$ and thymol content $(47.46 \%)$. In the case of micronutrients application, foliar spray of $\mathrm{ZnSO}_{4}$ at $0.5 \%$ produced maximum essential oil content of $3.02 \%$, fixed oil content of $8.39 \%$ and higher thymol content of $47.16 \%$. It was also evident that an essential oil content of $3.36 \%, 8.99 \%$ fixed oil and $49.21 \%$ thymol was recorded with combined application of $50 \%$ of RDN through vermicompost along with seed priming with Azospirillum and foliar application of zinc.

The results of the present study revealed that vermicompost had significant effect on essential oil content, fixed oil content and thymol per cent of ajwain. Vermicompost application through increased mineral uptake such as nitrogen and phosphorus has a positive effect on biomass production and subsequently enhances the essential oil content (Darzi et al. 2013). Nitrogen fixing bacteria, Azospirillum stimulates the uptake of nitrogen in the soil, increases the synthesis of secondary metabolites, and thus increases the amount of essential oil content. Similar results were also reported by Garg (2007) and Mahfouz \& Eldin (2007) in fennel and Aishwarya \& Amitabh (2015) in coriander and similar values of essential oil and thymol contents were reported by Chahal et al. (2017) \& Yogita et al. (2013) in ajwain.

\section{Economics}

Gross returns, net returns and benefit cost ratio were worked out by taking into consideration the inputs used for crop production, and the crop produce obtained. The highest benefit cost ratio (BCR) of 3.33 was recorded with combined application of $50 \%$ of RDN through FYM along with seed priming with Azospirillum and foliar spray of $\mathrm{ZnSO}_{4}$ at $0.5 \%$ even though maximum net returns was recorded with the application of $50 \%$ of RDN through vermicompost along with seed priming with Azospirillum and foliar spray of $\mathrm{ZnSO}_{4}$ at $0.5 \%$. The net returns obtained per rupee invested was high at $50 \%$ RDN applied through FYM, since the cost of FYM was comparatively less.

The substitution of inorganic nutritional source with organics significantly influenced the yield and quality aspects of ajwain. Among the organic sources, $50 \%$ of RDN through VC and $50 \%$ of RDN through FYM was found superior in improving the yield and yield attributes. The biochemical analysis revealed that quality parameters of the seeds like higher essential oil, fixed oil and thymol content were significantly improved by application of VC. Among the PGPRs, seed priming with Azospirillum was found significantly superior in promoting yield attributes and quality components. Among the micronutrients, foliar spray of $\mathrm{ZnSO}_{4} @ 0.5 \%$ was found promising with highest yield and other quality parameters.

Among the combined effect of organic manures, PGPR and micronutrients, application of 50\% of RDN through vermicompost + seed priming with Azospirillum + foliar spray of $\mathrm{ZnSO}_{4} @$ $0.5 \%$ and with $50 \%$ of RDN through FYM + 
Table 2. Essential oil content, fixed oil content and thymol content of ajwain as influenced by organic manures, plant growth promoting rhizobacteria and micronutrients (Mean of two years)

\begin{tabular}{cccc}
\hline & $\begin{array}{c}\text { Essential oil content } \\
(\%)\end{array}$ & $\begin{array}{c}\text { Fixed oil content } \\
(\%)\end{array}$ & $\begin{array}{c}\text { Thymol content } \\
(\%)\end{array}$ \\
\hline Organic manure $(\mathrm{A})$ & & & 47.65 \\
\hline $\mathrm{A}_{1}$ & 3.09 & 8.58 & 45.19 \\
$\mathrm{~A}_{2}$ & 2.74 & 7.84 & 47.89 \\
$\mathrm{~A}_{3}$ & 3.14 & 8.63 & 45.71 \\
$\mathrm{~A}_{4}$ & 2.83 & 7.96 & 0.07 \\
$\mathrm{SEm} \pm$ & 0.02 & 0.15 & 0.20 \\
$\mathrm{CD}(\mathrm{P}=0.05)$ & 0.04 & 0.41 & 47.46 \\
\hline Plant Growth Promoting Rhizobacteria $(\mathrm{B})$ & & 45.64 \\
\hline $\mathrm{B}_{1}$ & 3.09 & 8.51 & 46.73 \\
$\mathrm{~B}_{2}$ & 2.79 & 8.01 & 0.21 \\
$\mathrm{~B}_{3}$ & 2.98 & 8.24 & 0.58 \\
$\mathrm{SEm}$ & 0.03 & 0.10 & \\
$\mathrm{CD}(\mathrm{P}=0.05)$ & 0.09 & 0.25 & 47.16 \\
\hline Micronutrient $(\mathrm{C})$ & & & 46.06 \\
\hline $\mathrm{C}_{1}$ & 3.02 & 8.39 & 0.21 \\
$\mathrm{C}_{2}$ & 2.88 & 8.11 & 0.62 \\
$\mathrm{SEm} \pm$ & 0.04 & 0.10 & \\
$\mathrm{CD}(\mathrm{P}=0.05)$ & 0.11 & 0.25 &
\end{tabular}

Treatment details

\begin{tabular}{lll}
\hline A-Organic manure & B- Plant Growth Promoting Rhizobacteria & C-Micronutrient \\
$\mathrm{A}_{1}: 50 \%$ of RDN through FYM & $\mathrm{B}_{1}:$ Azospirillum & $\mathrm{C}_{1}: \mathrm{Zn} @ 0.5 \%$ \\
$\mathrm{~A}_{2}: 75 \%$ of RDN through FYM & $\mathrm{B}_{2}:$ Phosphorus Solubilising Bacteria (PSB) & $\mathrm{C}_{2}:$ Fe $@ 0.5 \%$ \\
$\mathrm{~A}_{3}: 50 \%$ of RDN through VC & $\mathrm{B}_{3}:$ Potash Mobilizing Bacteria (KMB) & \\
$\mathrm{A}_{4}: 75 \%$ of RDN through VC & & \\
\hline
\end{tabular}

seed priming with Azospirillum + foliar spray of $\mathrm{ZnSO}_{4} @ 0.5 \%$ were found on par in yield and yield attributes. Oil quality in terms of biochemical parameters like essential oil content, fixed oil content and thymol content were found to be significantly superior with substitution of nutritional source using vermicompost at $50 \%$ level along with seed priming with Azospirillum and foliar spray of $\mathrm{ZnSO}_{4} @ 0.5 \%$.

The economic analysis using organic manures, PGPR and micronutrients revealed that less cost of cultivation and maximum gross and net returns were obtained with $50 \%$ of RDN through FYM along with seed priming with Azospirillum and foliar spray of $\mathrm{ZnSO}_{4}$ at $0.5 \%$.

\section{References}

Anonymous 2000 Association of official analytical chemists. Official methods of analysis. Official Agriculture Chemistry. $16^{\text {th }} \mathrm{Ed}$. AOAC, Washington. D.C. pp 516-520.

Aishwarya D \& Amitabh N 2015 Impact of micronutrient application in Coriander (Coriandrum sativum L.) cv. CO4. Adv. J Seed Sci. Tech. 2: 42-46. 
Chahal K K, Dhaiwal K, Kumar A, Kataria D \& Singla N 2017 Chemical composition of Trachyspermum ammi $\mathrm{L}$ and its biological properties: A review. J. Pharma. Phytochem. 6: 131-140.

Darzi M T, Mahnaz S \& Mohammadreza H S H 2013 Effects of vermicompost and azotobacter and azospirillum bacteria on quantity and quality of essential oil of coriander (Coriandrum sativum L.). Intl. J. Farm. Allied Sci. 2: 12771283.

Folch J, Lees M \& Solane Stanley G H 1957 Isolation and purification of total lipids from tissues. J. Biol. Chem. 226: 497.

Garg V K 2007 Effect of non-symbiotic microbial inoculants on growth, yield and quality of fennel (Foeniculum vulgare Mill.) grown in sodic soil. J. Spices Arom. Crops 16: 93-98.

Hopkins W G 1995 Introduction to plant physiology. New York: John Wiley, pp.464.

Mahfouz S A \& Sharaf E M A 2007 Effect of mineral vs. biofertilizer on growth, yield, and essential oil content of fennel (Foeniculum vulgare Mill). Intl. Agrophy. 21: 361-366.

Panse V G \& Sukhatme P V 1978 Statistical methods for Agricultural workers. Indian Council for Agricultural Research, New Delhi.

Ravi M T 2016 Effects of Vermicompost (VC) and Farmyard Manure (FYM) on the germination percentage growth biochemical and nutrient content of coriander (Coriandrum sativum L.). Intl. J. Adv. Res. Bio. Sci. 3: 91-98.

Sega TY \& Kitajima J 2001 Water-soluble constituents of jowan. Chem. Pharma. Bulln. 49: 840-844.

Sharma S K, Singh H \& Kohli U K 1999 Influence of boron and zinc on seed yield and quality in radish. Seed Res. 27: 154-158.

Shekofteh H, Shafie S \& Mahmodi Y 2013 A survey on the effects of manure and chemical fertilizers and their mixture on ajowan's seed yield and its essential oil compositions. Intl. J. Agri. Res. Rev. 3: 401-408.

Sreenivas C, Muralidhar S \& Rao M S 2000 Vermicompost: a viable component of IPNSS in nitrogen nutrition of ridge gourd. Annls. Agri. Res. 21: 108-113.

Yogesh K A, Ramchandra \& Hemant K 2016 Effect of organic fertilizers on growth and yield of coriander (Coiandrum sativum) under subabul (Leucaena leucocephala) alley cropping system. Intl. J. Farm Sci. 6: 104-108.

Yogita R, Nikam T D \& Dhumal K N 2013 Effect of foliar application of plant growth regulators on growth, yield and essential oil components of ajwain (Trachyspermum ammi L.). Intl. J. Seed Spices 3: 34-41.

Zarshenas M M, Petramfar P, Semani S M \& Moein M 2014 Analysis of the essential oil components from different Carum copticum L. samples from Iran. Pharma. Res. 6: 62-66. 